Surv. Synth. Path. Res. 1983;2:I-IV

\title{
Contents, Vol. 2, 1983
}

\section{Editor-in-Chief}

J.M. Cruse, Jackson, Miss.

Senior Editor

R.E. Lewis, Jr., Jackson, Miss.

Advisory Editors

M.M. Azar, Minneapolis, Minn. S. Azar, Minneapolis, Minn. A.B. Jenson, Washington, D.C.

L.M. Schwartz, East Orange, N.J.

Topic Editors

Inflammation and Repair H.Z. Movat, Toronto

Atherosclerosis

R.M. O’Neal, Jackson, Miss.

Carcinogenesis and Cellular Injury

D. Kaufman, Chapel Hill, N.C.

Carcinogenesis

E. Farber, Toronto

Tumor Virology

W.H. Kirsten, Chicago, Ill.

Tumor Cell Biology

R.C. Gallo, Bethesda, Md.

Natural Killer Cells and Tumor Immunology

E. Lotzová, Houston, Tex.

Immunochemistry of Human Carcinomata

G.F. Springer, Evanston, Ill.

Neoplasia

W.W. Johnson, Jackson, Miss.

Pathogenesis of Infection

P. Bonventre, Cincinnati, Ohio

Immunopathology

M. Ginsberg, La Jolla, Calif. R. Ulevitch, La Jolla, Calif.

Hemostasis and Thrombosis

F.B. Taylor, Jr., Oklahoma City, Okla.

Cellular Injury, Ischemia and Shock B.F. Trump, Baltimore, Md.

Muscle and Neurologic Disorders W.W. Tourtellotte, Los Angeles, Calif.

Pulmonary Diseases

J. Hayes, Boston, Mass. 
Cardiovascular Diseases

M.D. Silver, London, Ontario

Congenital Disorders

H.S. Rosenberg, Houston, Tex.

Metabolic and Endocrine Disorders P. Heitz, Basel

Toxicology

F. Homburger, Cambridge, Mass.

Reticuloendothelial System Pathophysiology

N.R. DiLuzio, New Orleans, La.

Bone Marrow Transplantation H. Shulman, Seattle, Wash.

Host Defense Mechanisms A.C. Issekutz, Halifax R. Bortolussi, Halifax

Cytopathology

S.D. Greenberg, Houston, Tex.

Nutrition

R.B. McGandy, Boston, Mass.

Aging

K. Hirokawa, Tokyo

Clinical Pathology Reviews H. Rochman, Chicago, Ill.

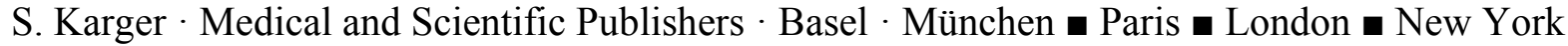

- Tokyo $\cdot$ Sydney

Drug Dosage

The authors and the publisher have exerted every effort to ensure that drug selection and dosage set forth in this text are in accord with current recommendations and practice at the time of publication. However, in view of ongoing research, changes in government regulations, and the constant flow of information relating to drug therapy and drug reactions, the reader is urged to check the package insert for each drug for any change in indications and dosage and for added warnings and precautions. This is particularly important when the recommended agent is a new and/or infrequently employed drug.

All rights reserved.

No part of this publication may be translated into other languages, reproduced or utilized in any form or by any means, electronic or mechanical, including photocopying, recording,

microcopying, or by any information storage and retrieval system, without permission in writing from the publisher or, in the case of photocopying, direct payment of a specified fee to the Copyright Clearance Center (see 'Information for Readers and Subscribers').

(C) Copyright 1983 by S. Karger AG,

P.O. Box, CH-4009 Basel (Switzerland)

Printed in Switzerland by Thür AG Offsetdruck, Pratteln

Contents Vol. 2,1983

No. 1-2 Interpretive Reviews

The Regulatory Role of Extracellular Proteases in Tumor Growth

McCabe, R.P.; Evans, C.H 1

Are the Biologic Activities of Fibronectin Controlled by Alterations in Its Molecular Form?

Hypothesis and Review

Colvin, R.B.; Kradin, R.L 10

Platelet Stimulus-Response Coupling and Regulation of Cytoskeletal Assemblies

Carroll, R.C.; Cox, A.C 21 
The Immune Functions of the Lung Alveolar Lining Material

Claypool, W.D.; Fisher, A.B 34

NK Cell Symposium

Function of Natural Killer Cells in Various Biological Phenomena. An Overview

Lotzová, E 41

Large Granular Lymphocytes Have a Regulatory Role on the Growth of Human Peripheral Blood T Cell and Erythroid Colonies

Pistoia, V.; Nocera, A.; Perata, A.; Leprini, A.; Ghio, R.; Ferrarini, M

Natural Cell-Mediated Cytotoxicity against Tumors in Mice

Lattime, E.C.; Stutman, $0 \quad 57$

Natural Killer Cell-Mediated Inhibition of Tumor Metastasis in vivo

Hanna, N 68

Mechanism of NK Cell Cytotoxicity

Roder, J.C.; Lauzon, R.J 82

In vivo Functions of Natural Killer Cells

Pollack, S.B 93

Hypothesis and Theory

A General Mechanism for Transmembrane Signalling Based on Clustering of Receptors

Brandts, J.F.; Jacobson, B.S 107

Editor's Column

Drug-Induced Lung Disease

Hayes, J.A 115

Clinical Pathology Review

Current Laboratory Tests for Assessing Nutritional Status

Sauberlich, H.E $\quad 120$

Discussion on Methodology

DNA Methodologies in Diagnostic Microbiology

Tompkins, L.S.; Falkow, S 134

IV Contents

No. 3-4 Interpretive Review

Triple Role of T and Tn Antigens in Cancer: as Universal, Clonal Carcinoma Markers, in

Cancer Cell Adhesion, and as Autoimmunogens

Springer, G.F 141

Symposium

The Role of Calcium Deregulation in Cell Injury and Cell Death (Introduction)

Trump, B.F.; Berezesky, I.K 165

The Role of Calcium in Cell Injury. Studies in Ehrlich Ascites Tumor Cells following Injury with Anoxia and Organic Mercurials

Laiho, K.U.; Berezesky, IX; Trump, B.F 170

Calcium Toxicity as a Factor in Spinal Cord Injury

Balentine, J.D 184

Myocardial Calcium Regulation in Disease

Jacobson, M.S.; Ambudkar, I.S.; Shamoo, A.E 194

The Ionic Regulation of Cell Reproduction in Normal and Tumor Cells

Cameron, I.L.; Smith, N.K.R 206

Role of Membranes in Calcification 
Kim, K.M 215

Editor's Column

Diagnosis of Sputum Atypias by Cell Image Analysis: A Review (with 1 color plate)

Greenberg, S.D 229

Conceptual Review

Histogenesis of Preneoplastic and Neoplastic Lesions in Tracheobronchial Epithelium McDowell, E.M.; Trump, B.F235

Author Index 280

Subject Index 281 